\title{
85732 - A UTILIZAÇÃO DO WHEY PROTEIN NA SUPLEMENTAÇÃO DE IDOSOS
}

\author{
Pôster - Gerontologia
}

\author{
Liziane da Rosa Camargo / Camargo, LR / PUCRS; \\ Divair Doneda / Doneda, D / UFRGS; \\ Viviani Ruffo de Oliveira / Oliveira, VR / UFRGS
}

Introdução: A nutrição é fundamental à saúde dos idosos e a proteína é um nutriente-chave, mas a maioria deles tem ingestão insuficiente de proteínas de alto valor biológico. A utilização do whey protein pode ser uma estratégia nutricional para aumentar o aporte proteico. Podendo melhorar o desempenho muscular ao estimular a síntese proteica. Objetivo: Analisar a literatura sobre a utilização do whey protein em idosos. Métodos: Revisão sistemática. Critérios de inclusão: população: idosa; intervenção: utilização de whey protein, comparada com grupo controle; desfecho: relacionado à saúde, nutrição ou qualidade de vida. Base de dados: PubMed, com artigos publicados nos últimos 5 anos. Estratégia de busca: (elder OR senior OR elderly OR aging OR aged OR old OR older) AND (whey OR "whey protein"). Resultados: Foram selecionados 35 artigos, sendo 22 com desfecho de desempenho físico e 13 com desfechos clínicos. Estudos indicam que suplementos a base de whey protein promovem síntese proteica em idosos, melhorando desempenho muscular, capacidade aeróbica, prevenindo sarcopenia e reduzindo o risco de quedas. Nos artigos encontrados, a faixa etária considerada para idosos foi de $\geq 65$ anos em 27 artigos e de $\geq 60$ anos nos 8 demais artigos. Eles também parecem contribuir para a melhoria da saúde, recuperação de doenças, prevenção de riscos cardiovasculares e metabólicos e nas complicações da esteatose hepática. Conclusão: Os dados sugerem que suplementação com whey protein pode ser promissor na manutenção muscular e funcionalidade. Além de recuperação de doenças, melhorando assim, a qualidade de vida dos idosos.

Palavras-chave: Proteínas do Soro do Leite; Nutrição do Idoso; Suplementação Alimentar. 